\author{
ACTA AGROBOTANICA \\ Vol. 63 (2): 25-32 \\ 2010
}

\title{
THE STRUCTURE OF SOME FLORAL ELEMENTS AND THE NECTAR PRODUCTION RATE OF Polemonium caeruleum $\mathrm{L}$.
}

\author{
Mirosława Chwil \\ Department of Botany, University of Life Sciences in Lublin, Akademicka 15, 20-934 Lublin, Poland \\ e-mail: miroslawa.chwil@up.lublin.pl
}

Received: 12.07.2010

\begin{abstract}
The present study, carried out in the period 2008 - 2009, covered some morphological and anatomical features of the flowers of Polemonium caeruleum L. and their nectar production rate in the climatic conditions of the Lublin region. Observations were made with stereoscopic, light and scanning electron microscopy. Nectar production in the flowers was determined using the pipette method.

The flowers of Polemonium caeruleum develop a calyx covered by an epidermis with numerous non-glandular and glandular trichomes. The secretory trichomes are composed of a several-celled stalk and a four-celled head. At the boundary of the corolla tube and the lobes, there is white colouration with violet nectar guides. The epidermis in this region produces several-celled living trichomes that close the entry into the corolla tube, thereby protecting the nectar accumulated in it. These hairs are at the same time glistening colour attractants for insects. The tripartite stigma of the pistil is covered, from the adaxial side, by unicellular papillae with striated cuticular ornamentation, growing at high density. Around the ovary there is located a nectariferous disc, in the form of a free projection, which secrets nectar with sugar concentration of $29-52 \%$ and sugar weight ranging $1.1-1.8 \mathrm{mg} /$ flower.
\end{abstract}

Key words: Polemonium caeruleum L., flower, micromorphology, anatomy, trichomes, stigma, papillae, nectar, secretion

\section{INTRODUCTION}

The genus Polemonium belongs to the family Polemoniaceae that includes 18 genera and 316 species. Many of them are found in the temperate and subtropical climate zones (K or n aś and Me d w e c k aK or n a ś, 2002).

Jacob's ladder (Polemonium caeruleum L.) grows in the natural environment in moist areas of the north-eastern part of Poland $(\mathrm{Zaj}$ ąc and $\mathrm{Zaj}$ ąc, 2001; Mirek and Piękoś-Mirkowa, 2008).
Its generic name comes from the name of the mythical king of Pontus, Polemon, while the second component of its name is derived from the word caelum that means "heaven", probably due to the blue colour of the corolla (R e je w s k i, 1996).

Polemonium caeruleum is a rhizomatous perennial with an erect stem growing up to a height of $120 \mathrm{~cm}$. It flowers from June to August. Its blue flowers with a diameter of $3 \mathrm{~cm}$ are borne on short pedicles and clustered in an apical panicle composed of cymes (Rutkowski, 2008; Witkowska-Żuk, 2008).

This species belongs to protected plants. The threat to this species arises from changes in habitat conditions taking place due to land drainage (S z w e y k ow s c y, 1993). Jacob's ladder has been included in ornamental plants (Marcinkowski, 2005), medicinal plants (the presence of flavonols, phytosterols, essential oils) (Lewkowicz-Mosiej, 2003; Ko siński and Krzyściak-Kosínska, 2008), and melliferous plants (K o ł tow s ki, 2006). It has been shown that the flowers of several taxa of the genus Polemonium are pollinated by honey bees, bumble bees, and wasps (Galen and New port, 1987; Galen and Stanton, 1989; Galen and Geib, 2007; Hill et al. 2007).

The aim of the present study was to examine some morphological and anatomical features of the flowers of $P$. caeruleum as well as to determine nectar forage provided by this species in the climatic conditions of the Lublin region.

\section{MATERIALS AND METHODS}

The study of the structure of the flowers and nectar production of Polemonium caeruleum L. was conducted in the period 2008 - 2009. The plants came from the Botanical Garden of the Maria Curie- 
Skłodowska University in Lublin. Initial observations and morphometric measurements were performed on selected floral elements and photographic documentation was made using a stereoscopic microscope equipped with a NICON COOLPIX 4500 camera.

Flowers for examination were sampled at the initial flowering stage. Portions of sepals, staminal filaments, the stigma of the pistil, and the ovary with the nectary were fixed in $4 \%$ glutaraldehyde at room temperature for 6 hours and in $0.1 \mathrm{M}$ phosphate buffer with a pH of 7.0 at $4^{\circ} \mathrm{C}$ for 24 hours. The fixed plant samples were postfixed in $1 \% \mathrm{OsO}_{4}$ for 2 hours and stained in a $0.5 \%$ aqueous solution of uranyl acetate. After dehydration in alcohol and acetone series, the plant material was critical-point dried in liquid $\mathrm{CO}_{2}$ in an EMITECH K850 drier, and then it was coated with gold using an EMITECH K550X sputter coater. Observations of the trichomes on the sepals and staminal filaments, the papillae on the stigma surface, and of the location of the nectaries were made in a TESCAN VEGA II LMU scanning electron microscope (SEM).

After dehydration ethanol series, the fixed samples were embedded in Spurr's low viscosity resin. 0.8 $-1 \mu \mathrm{m}$ thick sections were cut with a glass knife on a Reichert Ultracut S microtome. The semi-thin sections were stained with toluidine blue and observed in a Nikon Eclipse 400 light microscope. In the slides for fluorescence microscopy (Nikon Eclipse 90i) analysis, auramine staining was used (W ę d z o n y, 1996). The PAS reaction was applied to detect starch (N e v a la in en et al. 1972).

The nectar was collected at full flowering stage, using the pipette method described by $\mathrm{J}$ a b ł o ń s k i (2003), in five samples and three replicates. The amount of nectar secreted by $5-10$ flowers throughout their whole lifetime was one sample.

\section{RESULTS}

Calyx. The blue flowers of Polemonium caeruleum have a 5-sepalled calyx, which is much shorter than the corolla with fused petals (Fig. 2A, B). In crosssectional view, the calyx is made up of $4-6$ cell layers, including the epidermis and parenchyma (Fig. 2F). The parenchymal cells adjacent to the epidermis have a much smaller diameter than the cells of the other layers of this tissue. In their parietal cytoplasm, there occur numerous plastids that contain starch grains (PAS reaction) (Fig. 3D). The abaxial epidermal cells of the calyx form densely growing glandular and non-glandular trichomes (Figs 2C-G; 3A-C, E, F).

The glandular trichomes in the epidermis of the calyx are composed of a several-celled $(2-6)$ stalk with a length ranging $131-249 \mu \mathrm{m}$ and a four-celled head with a height of $24-31 \mu \mathrm{m}$ and a diameter of 31
$-43 \mu \mathrm{m}$ (Figs 2C, E- G; 3A, B). The protoplast of the head cells showed intense fluorescence (Fig. 3 B).

The non-glandular trichomes are found most frequently on the calyx; they are much shorter than the glandular hairs and composed of $2-3$ cells (Figs 2E, F; 3A, C, E, F), less frequently $4-5$. A striated cuticle occurs on the surface of both types of hairs (Fig. 2F).

Corolla and staminal filaments. At the boundary of the corolla tube and the lobes, there is white colouration. Three violet nectar guides, in the form of branched lines, are visible on each lobe (Fig. 2A). Non-glandular trichomes, most frequently composed of $2-3$ cells, and glandular trichomes with a short unicellular stalk grow on the corolla between the bases of the free staminal filaments (Fig. 3G, H). The filaments of five stamens are bent towards the pistil above the point of attachment to the corolla (Fig. 2D). The epidermis covering the filaments at this place, from the adaxial side, forms numerous trichomes. Multicellular uniseriate and two-branched non-glandular trichomes were observed among them (Fig. 4A, B). The cuticle on their surface was smooth (Fig. 4B).

Pistil. In the flowers of Polemonium caeruleum, the pistil develops a superior ovary $(1.6 \mathrm{~mm}$ in diameter), a long violet style $(13.3 \mathrm{~mm})$, and a three-parted stigma (Fig. 2A). The cuticle is smooth on the surface of the epidermal cells of the ovary. The stomata are found at higher density near the place where the carpels are fused. The guard cells are located at the level of other epidermal cells of the ovary (Fig. 4C).

In the adaxial epidermis of the stigma, numerous elongated papillae $(75-95 \mu \mathrm{m})$ grow densely (Fig. 4D - H). The cuticle forms longitudinal striae on their surface (Fig. 4E). The unicellular papillae are not fused together. A large cell nucleus located at their base and fine vacuoles are found in the protoplast of these structures (Fig. 4F - H). Between the papillae, pollen grains were observed at some places (Fig. 4D, E). These grains are multiporate with vermiculate, striate sculpture of the exine surface (Fig. 4E).

Nectar secretion. In the flowers of Polemonium caeruleum, droplets of nectar are visible already at bud burst. The nectar is secreted by the nectariferous disc situated around the ovary (Figs 2D; 4C). The green-coloured nectary forms free projections. A sweet secretion initially accumulates in the form of droplets on the surface of the nectary epidermis, then it flows down to the lower part of the corolla tube, whence it is collected by pollinating insects, mainly honey bees (Fig. 2B).

The weight of nectar secreted throughout the flower lifetime ranges between 2.56 and $4.25 \mathrm{mg}$, while sugar concentration in the nectar averages $41.8 \%$, with its extreme values of $29 \%$ and $52 \%$. Sugar weight is in a range of $1.07-1.78 \mathrm{mg} /$ flower (Fig. 1). 


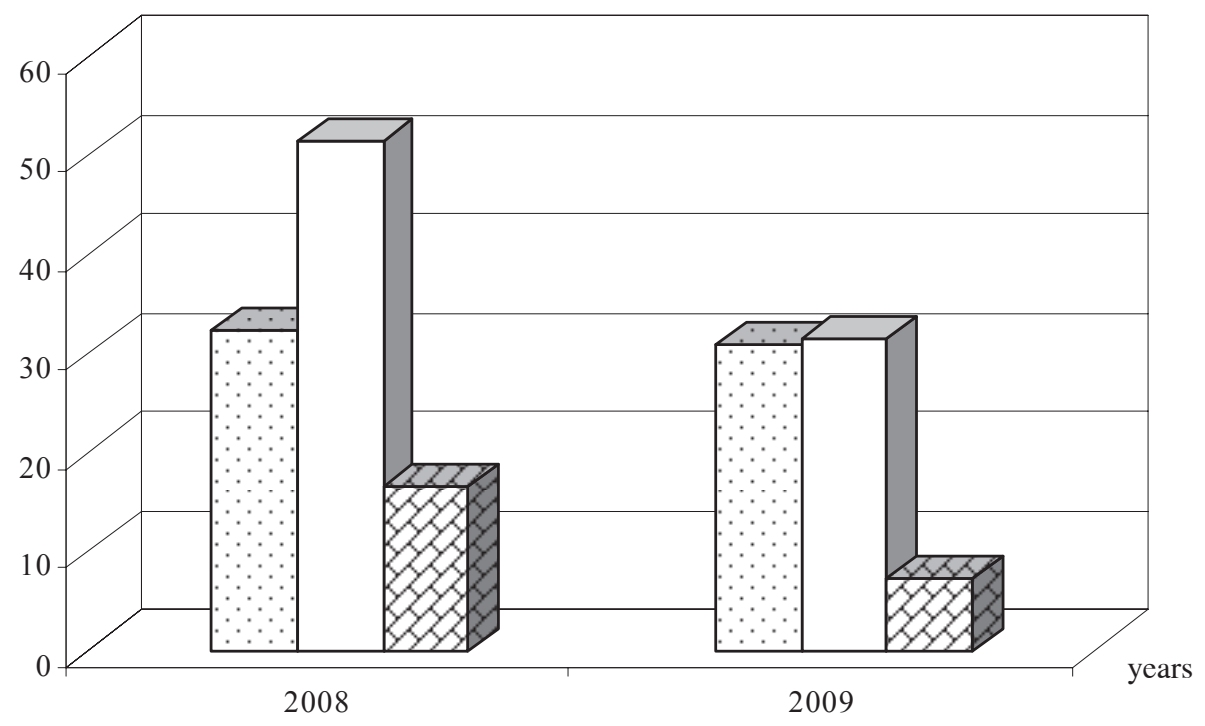

$\square$ nectar weight (mg/10 flowers) $\square$ sugar concentration in nectar (\%) $\quad \square$ sugar weight (mg/10 flowers)

Fig. 1. The nectar production rate of Polemonium caeruleum flowers

\section{DISCUSSION}

The blue colour of Polemonium caeruleum flowers is determined by delphinidin present in the petals (H a rborne, 1997). According to many authors, Apis mellifera prefer flowers in blue, yellow or white colour as the dominant colours $(\mathrm{S} \mathrm{z}$ a f e $\mathrm{r}$ and W oj tu s i a k o w a, 1969; K u g l e r, 1970; ; H a r b orne, 1997). In the investigated flowers, various floral elements have such colours: corolla lobes, stamen heads as well as the glistening trichomes of the corolla and filaments. These hairs close the entry into the corolla tube, protecting the nectar accumulated in it against small insects and evaporation, likewise in other species ( $\mathrm{S}$ z afer and Wojtusiakow a 1969; K u g l e r, 1970; E s a u, 1973; W erker et al. 1994; H a rborne, 1997).

The trichomes on the epidermal surface of the calyx consist of a several-celled stalk and a four-celled head. A different type of hairs growing on the abaxial surface of the calyx of Polemonium reptans is described by S c hön e n berger (2009). The trichomes presented by this author form a severalcelled stalk and a unicellular head. Compared to the data obtained by the present author, in P. caeruleum there are differences relating to the structure of the trichome head. Two types of glandular hairs, with a unicellular or multicellular head, have also been observed in other plant species of the family Polemoniaceae
(Metcalfe and Chale,1979; Schönenberg e r, 2009).

Numerous multicellular uniseriate and branched non-glandular trichomes as well as short-stalked glandular hairs are observed at the base of the lobes and staminal filaments in the studied flowers. On the basal surface of the lobes and stamens in the flowers of several Polemonium caeruleum subspecies, K o j i (1983) distinguished three groups of hairs: short trichomes composed of $3-5$ cells, long covering trichomes made up of $6-9$ cells, and glandular trichomes. In the presented study, a different, dichotomously branched type of non-glandular trichomes was observed.

According to Es a u (1973) and K o j i (1983), the structure of the secretory trichomes can be helpful in taxon identification. An important function of essential oils secreted by them is to lure pollinators (E s a u, 1973; H a r b o r n e, 1997).

The glandular epidermis of the tripartite stigma in the flowers of $P$. caeruleum develops unicellular papillae on the entire adaxial surface. Schönenb e r g e r (2009) described a similar location of these structures on the sigma of Polemonium reptans.

In the flowers in question, the papilla cells are elongated and free. Their protoplasts are characterized by a large nucleus, a dense cytoplasm, and tiny vacuoles. The papillae are responsible for creating optimal conditions for the development of the pollen tube and its penetration into the stigma structures $(\mathrm{Edlund}$ 

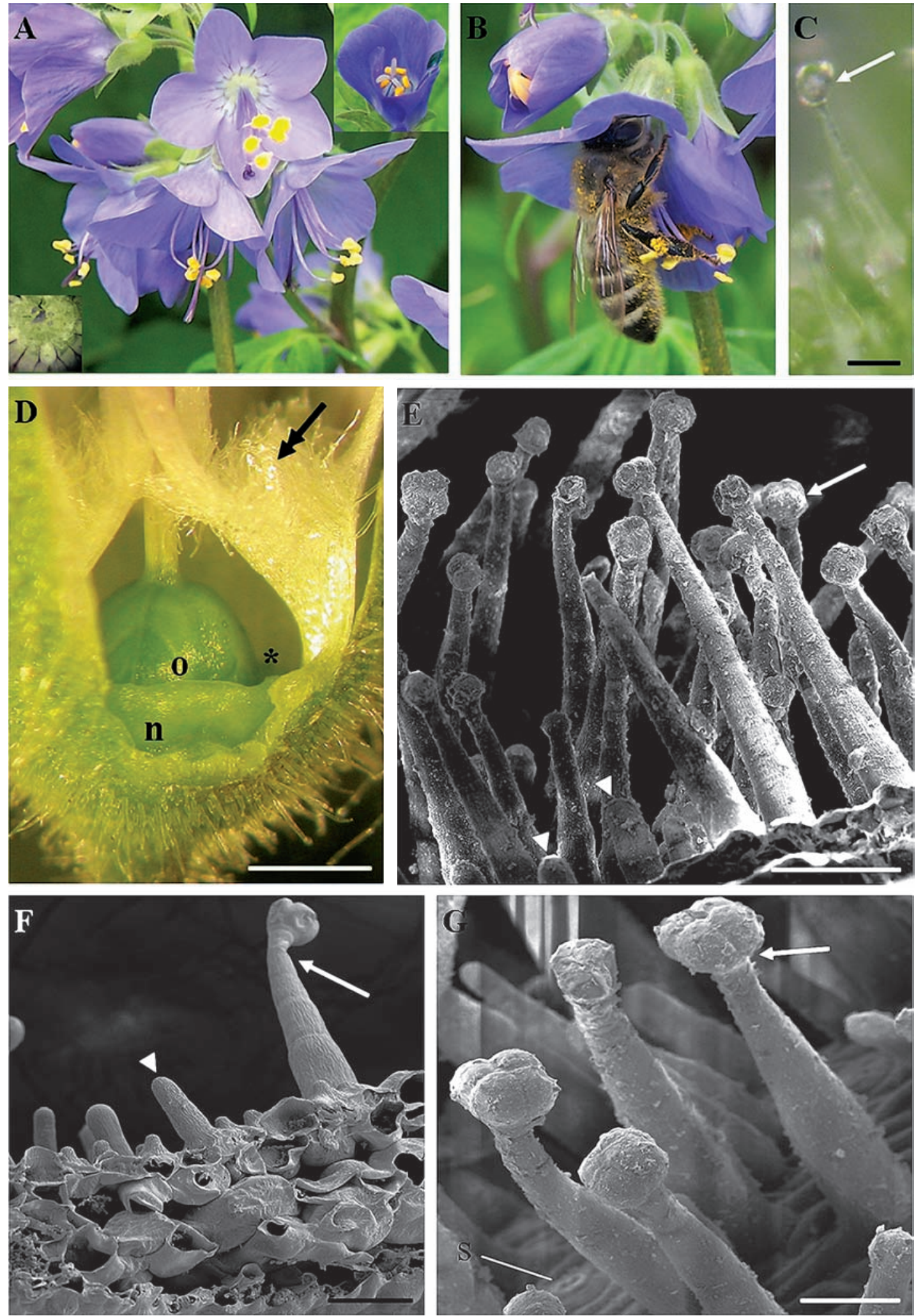

Fig. 2A, B. Parts of an inflorescence of P. caeruleum

Fig. 2C-G. Trichomes on the floral elements of P. caeruleum: C, E - G - glandular (arrow) and non-glandular trichomes (arrowhead) on the abaxial surface of the epidermis of the calyx; stoma (s) visible between the trichomes; $\mathrm{D}$ - longitudinal section of the perianth and receptacle, visible is the nectary (n) around the ovary (o), trichomes (double-headed arrow) at the base of the stamens and lobes as well as the place of nectar accumulation (asterisk). Scale bars: C, G, F = 50 $\mu$; $\mathrm{D}=10 \mathrm{~mm} ; \mathrm{E}=100 \mu \mathrm{m}$ 

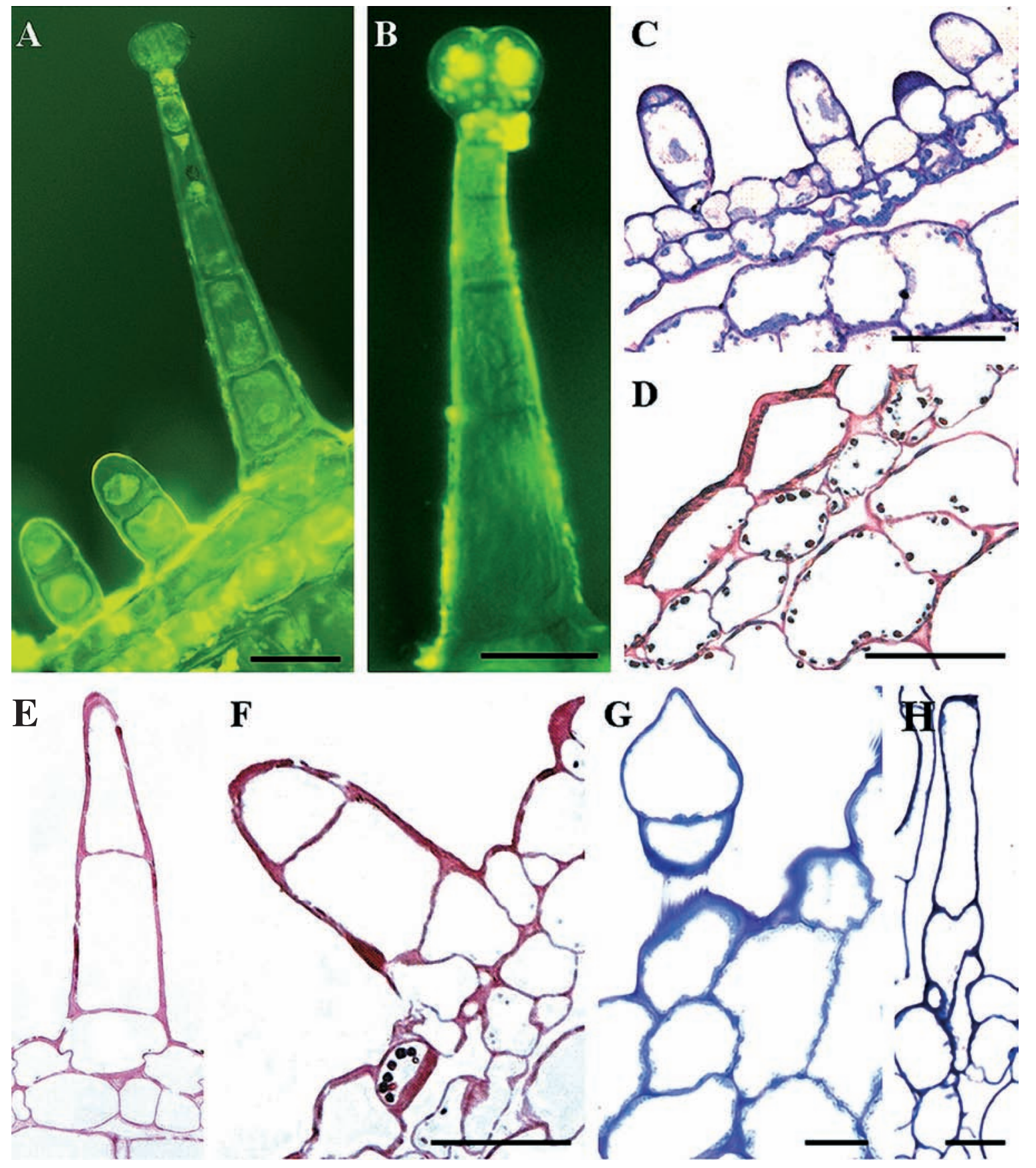

Fig. 3A - F. Trichomes on the sections of floral elements of P. caeruleum: A - F - on sepals; G, H - on the corolla near the base of the staminal filaments, visible a glandular and non-glandular trichome. Scale bars: $\mathrm{A}, \mathrm{C}-\mathrm{H}=50 \mu \mathrm{m}$; $\mathrm{B}=20 \mu \mathrm{m}$; $\mathrm{G}=100 \mu \mathrm{m}$ 

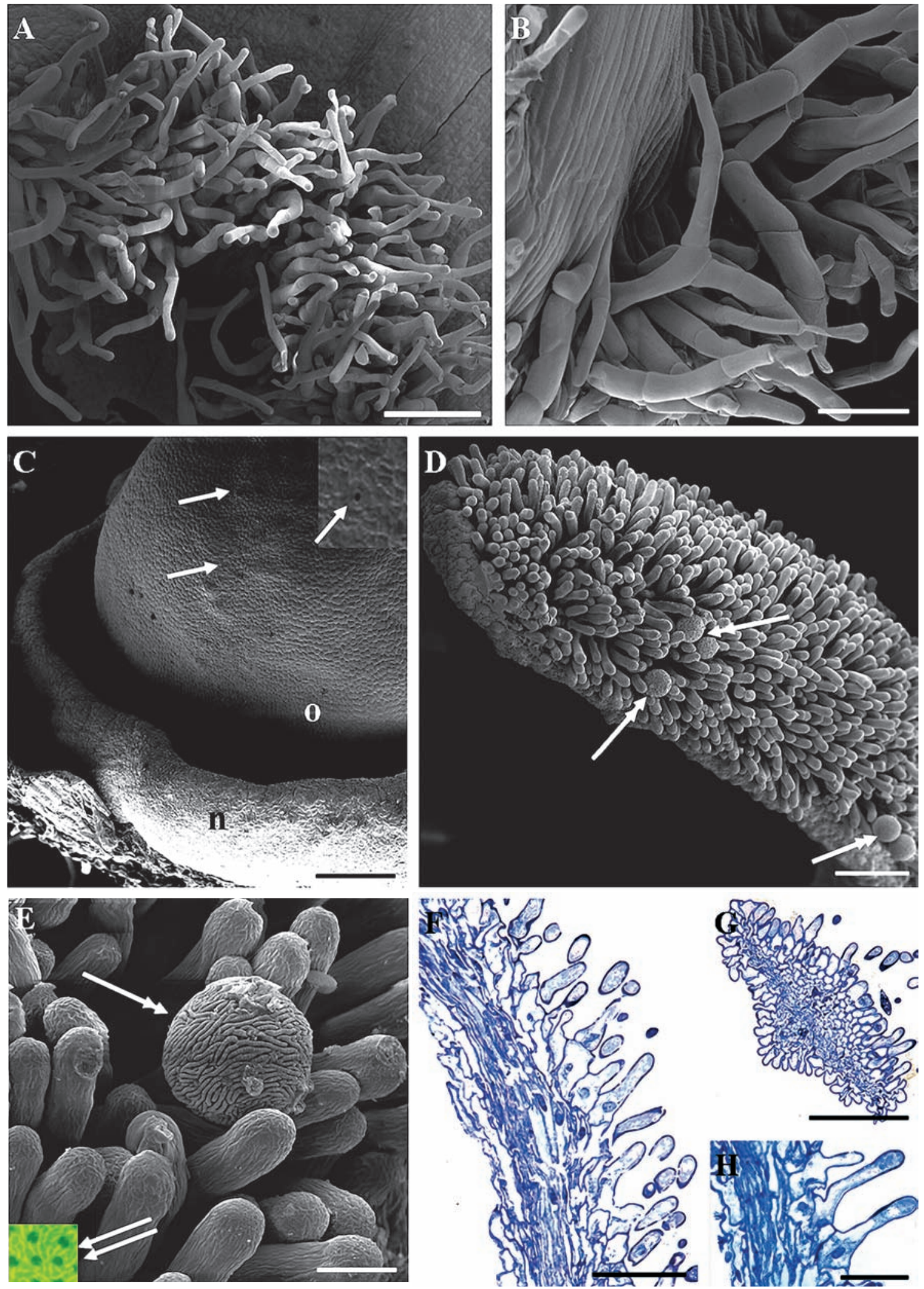

Fig. 4A - D. Portions of the floral elements of P. caeruleum: A, B - trichomes at the boundary of the lobes and staminal filaments, visible multicellular straight and branched trichomes; $\mathrm{C}$ - ovary (o) and nectary (n), visible stoma (arrow); D - H - the adaxial surface of the stigma with papillae, visible striated cuticular ornamentation (E), pollen grains (double-headed arrow) between the papillae (D, E), a portion of the exine surface (two arrows); F, H - cross section, $\mathrm{G}$ - longitudinal section. Scale bars: $A=200 \mu \mathrm{m} ; \mathrm{B}-\mathrm{D}=100 \mu \mathrm{m} ; \mathrm{E}=20 \mu \mathrm{m} ; \mathrm{H}=50 \mu \mathrm{m}$ 
et al. 2004). Other authors claim that the penetration of pollen tubes does not damage the surface of the papillae (Carmo-Oliveira 1 and Lange de Morretes , 2009).

The vermiculate, striate sculpture of the exine of pollen grains in the flowers of $P$. caeruleum corresponds with the reports of $\mathrm{Moe}$ (2001), who distinguishes in several species of the genus Polemonium two types of pollen grains: $P$. caeruleum and $P$. boreale. This author reports that the number of pores on the surface of pollen grains is 50 or more.

Pollen and nectar are collected from the observed flowers by the honey bee. During flower visitation observations conducted by $\mathrm{Hill}$ et al. (2008) in the flowers of $P$. vanbruntiae, visits of Apis mellifera ranged $55-66 \%$.

The nectaries of $P$. caeruleum, investigated in the present study, produce nectar abundantly (on average $3.16 \mathrm{mg} / \mathrm{flower}$ ). This value is higher than nectar weight $(0.2-2 \mathrm{mg}$ / flower $)$ given by $\mathrm{D}$ e $\mathrm{m} \mathrm{i} \mathrm{-}$ a now ic z (1953) for this taxon. Sugar weight in the examined nectar in the climatic conditions of the Lublin region averaged $1.2 \mathrm{mg} /$ flower. This value is within the range $(0.7-1.7 \mathrm{mg} /$ flower $)$ given for $P$. caeruleum growing in Ukraine, as reported by B odnar čuk et al. (1993). Honey yield of this species has been estimated in the literature at 70 up to $200 \mathrm{~kg}$ per ha (Bodnarćuk et al. 1993; Jabłoński, 1993; Kołtowski, 2006). Taking into account the fact that $P$. coeruleum is threatened with extinction and that its flowers produce nectar abundantly and are attractive to Apis mellifera, this species should be recommended for plantings of different types as an enrichment of food resources for pollinators.

\section{REFERENCES}

Bodnarčuk L. I., Solomacha T. D., Illjaš A. M., So lom ach a V. D., Gorov yj V. G., 1993. Atlas medonosnych roslyn Ukrainy. Urožaj, Kyiv (in Russian).

Carmo-Oliveira1 R., Lange de Morretes B., 2009. Stigmatic surface in the Vochysiaceae: reproductive and taxonomic implications. Acta Bot. Bras. 23 (3): 780-785.

Demi a nowicz Z., 1953. Rośliny miododajne. Państwowe Wydawnictwo Rolnicze i Leśne, Warszawa (in Polish).

Edlund A. F., Swans on R., Preus s D., 2004. Pollen and stigma structure and function: The role of diversity in pollination. Pollen and stigma structure and function: The role of diversity in pollination. Plant Cell. 16: S84-S97.

E s a u K., 1973. Anatomia roślin. Warszawa, Państwowe Wydawnictwo Rolnicze i Leśne (in Polish).

Galen C., Geib J. C., 2007. Density-dependent effects of ants on selection for bumble bee pollination in Polemonium viscosum. Ecology, 88 (5): 1202-1209.
Galen C., New port M. E. A., 1987. Bumble bee behavior and selection on flower size in the sky pilot, Polemonium viscosum. Oecologia, 74: 20-23.

G a le n C., S t a n t on M. L., 1989. Bumble bee pollination and floral morphology: factors influencing pollen dispersal in the alpine sky pilot, Polemonium viscosum (Polemoniaceae). Amer. J. Bot. 76 (3): 419-426.

Harborne J. B., 1997. Ekologia biochemiczna. Warszawa, Państwowe Wydawnictwo Naukowe (in Polish).

Hill L. M., Brody A. K, Tedescob C. L., 2008. Mating strategies and pollen limitation in a globally threatened perennial Polemonium vanbruntiae. Acta Oecologica, 33: 314-323.

J a b łoń s k i B., 1993. Ogródek pszczelarski. Puławy, Oddział Pszczelnictwa ISK w Puławach (in Polish).

J a błoń sk i B., 2003. Metodyka badań obfitości nektarowania kwiatów i oceny miododajności roślin. Puławy, Oddział Pszczelnictwa Instytutu Sadownictwa i Kwiaciarstwa (in Polish).

Koji I., 1983. The Polemonium in Hokkaido, the Kuriles and Sachalin. Environ. Sci. Hokkaido 6 (2): 247-280.

Koł tow s k i Z., 2006. Wielki atlas roślin miododajnych. Warszawa, Przedsiębiorstwo Wydawnicze Rzeczpospolita (in Polish).

Kornaś J., Medwecka-Kornaś A., 2002 Geografia roślin. Warszawa, Państwowe Wydawnictwo Naukowe (in Polish).

Kosiński M., Krzyściak-Kosińska R., 2008. Atlas ziół. Bielsko-Biała, Pascal (in Polish).

Kugle r H., 1970. Blütenökologie. Stuttgart, Gustav Fisher Verlag.

Lewkowicz-Mosiej T., 2003. Leksykon roślin leczniczych. Warszawa, Świat Książki (in Polish).

Marcinkowski J., 2005. Katalog bylin polecanych przez Związek Szkółkarzy Polskich. Marcinkowski J. 2005. Katalog bylin polecanych przez Związek Szkółkarzy Polskich. Warszawa, Agencja Promocji Zieleni. Związek Szkółkarzy Polskich (in Polish).

Metcalfe C. R., Chale L., 1979. Anatomy of the Dicotyledons. Oxford, Clarendon Press.

Mirek Z., Piękoś-Mirkowa H., 2008. Czerwona Księga Karpat Polskich. Kraków: Instytut Botaniki im. W. Szafera PAN (in Polish).

Moe D., 2001. Contribution to the flora history of the genus Polemonium with special reference to North Norway. Grana, 40: 292-298.

Neval a inen T. J., La it io M., Lindg ren I., 1972. Periodic acid - Schiff (PAS) staining of epon - embedded tissues for light microscopy. Acta Histochem. 42: 230233.

Rej e w s k i M., 1996. Pochodzenie łacińskich nazw roślin polskich. Warszawa, Książka i Wiedza (in Polish).

Rut kowski L., 2008. Klucz do oznaczania roślin naczyniowych Polski niżowej. Warszawa, Państwowe Wydawnictwo Naukowe (in Polish). 
S chön en berger J., 2009. Comparative floral structure and systematics of Fouquieriaceae and Polemoniaceae (Ericales). Int. J. Plant Sci. 170: 1132-1167.

Szafer W., Wojtusiakowa H., 1969. Kwiaty i zwierzęta. Warszawa, Państwowe Wydawnictwo Naukowe (in Polish).

S z we y kow s c y A. J., 1993. Słownik botaniczny. Warszawa, Wiedza Powszechna (in Polish).

Werker E., P ut ievs k y E., R a vid U., D ud a i N., K at zi r I., 1994. Glandular hair, secretory cavities and the essentials oil in leaves of tarragon (Artemisia dracunculus L.). J. Herbs Spices Med. Plants, 2 (3): 19-32.

Wę d z o n y M., 1996. Mikroskopia fluorescencyjna dla botaników. Kraków, wyd. PAN. ZFR (in Polish).

Witkowska-Żuk L., 2008. Atlas roślinności lasów. The flora of Poland. Warszawa, MULTICO.

Zając A., Zając M., 2001. Atlas rozmieszczenia roślin naczyniowych w Polsce. Kraków, Pracownia Chorologii Komputerowej Instytutu Botaniki Uniwersytetu Jagiellońskiego (in Polish).

\section{Struktura wybranych elementów kwiatowych i obfitość nektarowania Polemonium caeruleum $\mathbf{L}$.}

\section{Streszczenie}

Badania przeprowadzone w latach 2008 - 2009 obejmowały niektóre morfologiczne i anatomiczne cechy kwiatów Polemonium caeruleum L. oraz obfitość nektarowania w warunkach klimatycznych Lubelszczyzny. Obserwacje przeprowadzono przy użyciu mikroskopii stereoskopowej, świetlnej i skaningowej elektronowej. Nektarowanie kwiatów określono metodą pipetową.

Kwiaty Polemonium caeruleum wykształcają kielich okryty epidermą z licznymi włoskami ochronnymi i gruczołowymi. Włoski wydzielnicze utworzone są z kilkukomórkowej nóżki i czterokomórkowej główki. Na granicy rurki korony i łatek występuje białe przebarwienie z fioletowymi wskaźnikami drogi do nektaru. Epiderma tego regionu wytwarza żywe kilkukomórkowe trichomy, które zamykają wejście do rurki korony, zabezpieczając zgromadzony w niej nektar. Włoski te stanowią jednocześnie połyskujące atraktanty sygnalizacyjne dla owadów. Trójdzielne znamię słupka od strony doosiowej okryte jest wyrastającymi w dużym zwarciu jednokomórkowymi papillami z prążkowaną ornamentacją kutykularną. Wokół zalążni usytuowany jest dysk nektarnikowy w formie wolnego wzniesienia, który wydziela nektar o koncentracji cukrów $29-52 \%$ i ich masie oscylującej w granicach $1,1-1,8 \mathrm{mg} / \mathrm{kwiat}$. 